\title{
10
}

\section{Price Controls and Market Economies}

\author{
André Azevedo Alves and Inês Gregório
}

\subsection{Introduction}

Governments usually adopt price controls to impose restrictions on the price of goods and services by employing the appealing argument that they are protecting the groups who find it difficult to meet increasing prices. Since ancient times, regulators have set maximum or minimum prices - price ceilings or price floors. A maximum price for bread was understood as a means to protect the poorest from starvation and the maximum price for house rents to protect them from becoming homeless. The minimum wage - the price floor for labor - was seen as a guarantee to prevent unskilled workers from falling below a minimum living standard.

Nonetheless, many economists are skeptical about these mechanisms because they interfere with the natural operation of the market and distort the pattern of resource allocation. Additional objections sound not in utilitarianism but in moralism. By changing the prices that emerge from the free interaction of the participants on commercial exchanges, price controls pervert the relationship between price and worth. According to the moral objections, the former should reflect the latter for there to be a just exchange. Moreover, according to the objectors, price ceilings will, by definition, cause shortages, and 
price floors will lead to surpluses, therefore ending up penalizing precisely the groups that price controls were intended to protect. As such, the imposition of price controls, apart from having unintended consequences, appears to violate the principle of justice in economic transactions.

Price controls have been extensively discussed throughout the centuries, not only by economists, but by all sectors in society. In this chapter, we approach the question of price controls using a Christian framework, analyzing the arguments employed by recognized authors from various denominations. After a brief introduction, Section 10.2 explores the sources and origins of Christian thought on price controls and market economies, with a special emphasis on the medieval legacy, and in particular the thought and work of St. Thomas Aquinas. Section 10.3 discusses the main topic according to subsequent developments in Catholic thought, focusing mainly on late scholasticism, which was crucial in shaping Catholic views on economic issues in the transition to modernity. Section 10.4 approaches prices controls from the point of view of Protestant thought distinguishing between the perspective of three political economists Pufendorf, Hutcheson, and Smith - and the perspective of Martin Luther. Finally, Section 10.5 concludes the argument, with an attempt to synthesize (at least to the extent common ground can be found) a general Christian position on price controls and market economies. 


\subsection{Sources and Origins of Christian Thought on Price Controls and Market Economies: The Medieval Legacy}

Concerns about the justice of prices practiced in markets are not new. They may ultimately be traced back to antiquity, when the first forms of economic exchange emerge. Christian thought on price controls and market economies traditionally drew on two major sources. The first was, of course, the biblical texts from which divine law was ascertained and interpreted. The second was the Aristotelian tradition, particularly the framework for dealing with justice in exchange relationships set up in Aristotle's Nicomachean Ethics. As noted by the historian of medieval economic thought, Diana Wood:

In his Nicomachean Ethics ( $v, v)$ Aristotle set up a model of justice in exchange which is fundamental to the idea of the just price. He did not discuss the just wage as such, because the society in which he lived was based largely on slavery, but his model generated ideas amongst later commentators which were applicable to both subjects. Aristotle's real concern was to apply justice to exchange. In its widest sense he saw justice as a state of mind which disposed someone to act rightly. It was righteousness itself, and as such it was the epitome of all virtue. "Justice ... is not a part of virtue, but virtue entire." For him virtue consisted in a mean. The just or virtuous person was one who avoided all extremes, and whose disposition led him to apply the mean, or moderation, to his behaviour. Justice in the sense of righteousness 
was a universal quality. When he discussed justice in exchange, however, his concern was with "particular" rather than universal justice - justice as applied to relationships between people.

It was during the Middle Ages, when economic life developed significantly, that the doctrine of just price became a principal concern for medieval writers.

According to John Baldwin, the encapsulation of the medieval economy's doctrine of just price was that "the just price was essentially determined by the cost of production ... [and] consisted of the sum total of material costs necessary for producing goods plus a reasonable wage to maintain the craftsman or merchant in his appropriate station of life." As such, the reward for the effort put forth by craftsmen or merchants in the production of goods was differentiated by and directly associated with their position in the social hierarchy. It was possible to make these distinctions because the medieval economy was organized within the guild system; it was generally static, consisting of local and small markets, a limited number of buyers, and a level of goods supply that was either elastic or known to all participants on economic exchanges. Guilds, Raymond de Roover clarifies, consisted of "welfare agencies which prevented unfair competition, protected consumers against deceit and exploitation, created equal opportunities for their members, and secured

\section{Diana Wood, Medieval Economic Thought (Cambridge: Cambridge} University Press, 2002), p. 133.

2 John W. Baldwin, "The Medieval Theories of the Just Price: Romanists, Canonists, and Theologians in the Twelfth and Thirteenth Centuries," Transactions of the American Philosophical Society, vol. 49, no. 47 (1959), p. 7. 
them a modest but decent living in keeping with traditional standards."

Nonetheless, the quick and substantial progress in trade that took place between the eleventh and the thirteenth centuries - and which meant not only an increased number of commercial transactions but also the development of new financial tools - revived the debate about the justum pretium. And in the normative analysis of this economic question, three groups of medieval authors stood out: the Canon lawyers, the Roman lawyers, and the theologians.

Classical Roman law evidently influenced medieval Roman lawyers, and, for that reason, the principle of freedom of bargaining played a fundamental role for them in the question of price determination. According to the free-bargain principle, as explained by Odofredus in his Lectura, ${ }^{4}$ sellers and buyers were free to negotiate and to offer different prices before agreeing upon a certain price. To complement this process, medieval Roman lawyers also revived and generalized a device from the Justinian Code known as laesio enormis, which established that the price could be rectified if it was below one-half of the just price.5

On the other hand, discussion among Canon lawyers was dominated by the important concept of usury, which the Carolingian economic legislation

${ }^{3}$ Raymond de Roover, "The Concept of the Just Price: Theory and Economic Policy," The Journal of Economic History, vol. 18, no. 4 (December 1958), p. 418.

${ }^{4}$ Quoted in Baldwin, “The Medieval Theories of the Just Price," p. 21.

${ }^{5}$ In its original form, laesio enormis was developed to protect sellers, but during the Middle Ages, Roman lawyers extended its benefits to buyers as well. As explained by Baldwin, this development can be seen as "a revolution which deposed the seller from his place of privilege and elevated the buyer to at least an equal position" (ibid., p. 27). 
defined as "when more is demanded back than what is given." Early Canonists rejected any possibility of price profiteering and favored price regulation as a mechanism to protect both sellers and buyers from the abusive practice of usury. However, a few centuries later, the Decretists' interpretations of the Decretum of Gratian introduced an important difference between profit - honestus questus, which resulted from labor and the expenses of craftsmanship and was necessary for self-support - and usury, turpe lucrum, which resulted from speculative sale and greed. William of Rennes later confirmed this, arguing in favor of a moderate profit (lucrum moderatum) and clarifying that gains were only sinful if conducted out of greed (cupiditas):

Although business can scarcely be conducted without sin, merchants may receive a moderate profit from their ware for the maintenance of themselves and their families. Since they work for all and perform a kind of common business by transporting merchandise back and forth between fairs, they should not be held to pay their own wages. From the merchandise itself they can accept a moderate profit, which is regulated by the judgement of a good man, because the amount of profit permitted cannot be exactly determined in shillings, pounds, or pennies.

${ }^{6}$ Ibid., p. 32. In this point, it is possible to identify the general suspicion toward merchants and mercantile activity that was inherited from the ancient Church Fathers, who believed that commercial activity was always a "morally risky business" (ibid., p. 14) because money enhances the chances of fraudulent and deceitful attitudes by all participants in the exchange.

${ }^{7}$ Referring to the period of the late eighth and ninth centuries and including the laws and canons of the Carolingian Empire.

${ }^{8}$ Quoted in ibid., p. 48. 
But Romanists and Canonists were neighbors in Bologna, the center of the two legal systems at the time, and neither was immune to the influence of the other. Popes Alexander III and Innocent III introduced the device of laesio enormis into Canon law. For both systems, the just price was the current price; the price that goods currently fetched at a specific time and place. For this reason, the justum pretium resulted from a common estimation and fluctuated according to different localities or moments. 9 There was also a coincident view of the problem of fraud (dolus), which was considered to be a deliberate misrepresentation of the quality or quantity of goods.

Theologians did not seriously consider the question of just price until the thirteenth century; nonetheless, their intellectual accomplishments were even more remarkable than those achieved by medieval legists. ${ }^{10}$ Although not the first theologian advocating a just price of economic goods, Thomas Aquinas is often referred to as the father of the theory of just price because of his thorough

\footnotetext{
${ }^{9}$ Romanists developed a manual for estimatores, those who were responsible for determining the just price of goods The manual defined their duties to include "the determination of obligations between debtors and creditors, the appraisal of landed properties and their boundaries, the division among partners of things held in common, and the adjudicating of the right of way" (ibid., p. 28). Additionally, in his Lectura, Odofredus also established four standards for this estimation, the first and most important of which referred to the price that was "observed commonly," in contrast to the price that arose "from the whim or needs of single individuals" (ibid., p. 28). Following the same methods, Canonists emphasized the importance of leaving individual affections aside from the estimation of just price, which should be the result of a common estimation. Bernard of Botone left the influence by Romanists very clear when he stated the formula "a thing is worth as much as it can be sold for" as being the Canonist definition of just price (ibid., 54).

10 Ibid., p. 58.
} 
exposition of the topic. His careful analysis of the subject can be found in Question 77: "By Sins Committed in Buying and Selling" of Secunda-secundae of his Summa Theologica. Reflecting the prevailing view that economics was part of justice, Aquinas' objective was normative - to give a theoretical justification for the ethical character of prices.

In his first article, Aquinas asserts that it is sinful to sell a thing for more than the just price. Doing so is a form of deceit and of injury to the other party involved in the transaction. He proceeds to distinguish two different ways of buying and selling: the first that tends to be advantageous for both parties and the second that tends to the advantage of one party and the disadvantage of the other. Explaining the former type of transaction, Aquinas asserts that all contracts "should not be more of a burden to one party than to another, and consequently all contracts between them should observe equality of thing and thing." 11 For this reason, when the price exceeds the quality of the thing or the quality exceeds the price, there is no equality of justice, and the sale is unjust and unlawful. In this case, "to fulfil the demands of equitable justice the contract price and the true economic value of goods must be equivalent." 12 It is by focusing merely on passages similar to these that some authors have concluded that Aquinas follows Marxian dialectics and establishes a theory of value in line with Karl Marx. This theory, however, is deconstructed by Roover, who accuses these authors of "selecting those passages favorable to their thesis" 13 and of ignoring

\footnotetext{
${ }^{11}$ St. Thomas Aquinas, The Summa Theologica, trans. Fathers of the English Dominican Province (Cincinnati: Benziger Bros., 1947), II, II, q. 77, art. 1, ad resp.

12 Baldwin, "The Medieval Theories of the Just Price," p. 72.

13 Roover, "The Concept of Just Price," p. 421.
} 
other statements that completely contradict this theory, especially in the last article of Question 77.

Aquinas's second method of buying and selling, on the other hand, refers to those accidental situations "when a man has great need of a certain thing, while another man will suffer if he be without it." ${ }^{14}$ Here, the just price will be defined not only by the economic value of the thing sold, but also by the loss imposed on the seller. For it is thus possible "to sell a thing for more than it is worth in itself," 15 but never for more than it is worth for the seller. ${ }^{16}$ Before concluding the article, Aquinas separates human law from divine law and clarifies that, according to the latter, there should be compensation for those who suffer loss from unlawful contracts.

Defects in the thing sold are the main topic of Aquinas's next two questions, with a three-part classification - the fault may regard the thing's substance, its quantity, or its quality. In any case, Aquinas is very straightforward in affirming that if a sale is made with awareness of a fault, it is fraudulent and unlawful. But the same does not apply if the seller is not aware of the fault: "if any of the foregoing defects be in the thing sold, and he knows nothing about this, the seller does not sin."17 Nevertheless, the buyer always has the right to be

14 Aquinas, The Summa Theologica, II, II, q. 77, art. 1, ad resp.

15 Ibid.

16 On this point, Aquinas introduces two remarks that are important to understand the overall theory. If one person greatly benefits of the thing to be sold and if the seller does not suffer any loss by selling it, then the price shall not be raised, even though it is for the advantage of one party. Moreover, if a man buys something he considers to be to his great advantage, he may pay the seller a higher price for it; but the gesture belongs only to his honesty.

${ }^{17} \underline{\text { Ibid., art. 2, ad resp. }}$ 
compensated for the loss caused, even if the seller only learns of the defect after the sale is made. Another relevant point regarding the sale of faulty things respects the obligation of the seller to state the defects of the thing to be sold. If the seller acts otherwise, he would be giving someone "an occasion of danger or loss" and the contract would be fraudulent.

In the last article of the question, Aquinas addresses those situations where it is acceptable to sell a thing dearer than what the seller paid for it - the mark-up question. According to the author, exchange can be seen in two different ways, one by natural necessity - which he considers "commendable" - and the other one by profit, which he considers "deserving of blame." Gains considered in themselves, in their nature, are neither virtuous nor sinful; it is the final objective of trading that determines their justness:

Thus, for instance, a man may intend the moderate gain which he seeks to acquire by trading for the upkeep of his household, or for the assistance of the needy; or again, a man may take to trade for some public advantage, for instance, lest his country lack the necessaries of life, and seek gain, not as an end, but as payment for his labor.

In this point, Aquinas approaches the ideas of Aristotle, considering that, apart from reflecting the factors of labor and expenses, the economic value of a thing also reflects the concept of human want or need. Differences of value "were due, first of all, to the abilities of goods to satisfy need, and, secondly to the amounts

18 The author explains, however, that if the defects are too obvious, there is no need to inform the buyer.

$19 \underline{\text { Ibid., art. 4, ad resp. }}$ 
of labour and expenses expended in their production."20 Also in his comments on Aristotle, the theologian argues that "arts and crafts would be doomed to destruction if the producer did not recover his outlays in the sale of his product," thus arguing that "the market price could not fall permanently below cost." Therefore, for Aquinas, the just price cannot be determined with mathematical precision, being instead an estimate that takes into account the economic value of goods relative to a specific time and place. Moreover, the just price also enjoys some elasticity to "vary within a certain range, so that minor deviations do not involve any injustice."22 The example given to illustrate this argument can be found in Question 77, Article 3, Objection 4. Here, Aquinas tells a story about a merchant who arrives with wheat in a place that faces starvation. The merchant knows that other merchants are coming after him with more wheat. Is this merchant able to sell the wheat at a higher price due to the scarcity of the good or is he bound to tell the truth and to sell the wheat at a lower price than its prevailing price? According to Aquinas, the seller "does not seem to act contrary to justice through not stating what is going to happen," 23 even though he would act virtuously if he chose to do so and lowered the price accordingly.

As a theologian, Thomas Aquinas understood the just price as justice entering the world of commerce, and, probably for that reason, in his thought the just price takes precedence over the concept of laesio enormis as a limit to the free bargaining of contracts. The concept had traditionally acted as a limitation

\footnotetext{
20 Baldwin, "The Medieval Theories of the Just Price," p. 74.

21 Roover, "The Concept of Just Price," p. 422.

22 Ibid., p. 422.

${ }^{23}$ Aquinas, The Summa Theologica, II, II, q. 77, art. 3, ad resp.
} 
on the enforcement of agreements that would be deemed to result in abnormal harm (laesio enormis) inflicted on one of the parties. But for Aquinas, despite allowing for small deviations from the just price without resulting in a fraudulent sale, the integral just price (and not any stipulated fraction of it such as half or two-thirds) was regarded as the central concept for evaluating the justice of transactions. An implication of this is that, of course, computation of the just price then becomes a central issue for determining the proper role and scope of economic regulation and price controls. For this purpose, as explored in the next section, the notion of "common estimation" will play a key role.

Two additional points unanimously made by medieval authors are the rejection of any form of price discrimination to maintain a social hierarchy and the understanding of monopoly as "a deleterious practice, inimical to the commonweal."24 All practices adverse to competition were considered to be of a criminal nature and "those who escaped conviction in the secular courts were still punishable in foro conscientiae," 25 because monopoly profits corresponded to turpe lucrum, for which restitution was always required.

\subsection{Catholic Thought on Price Controls after the Reformation}

While Christian thought on price controls and market economies naturally had many variants, it is safe to say that the Thomistic framework explained in the previous section of this chapter was the dominant approach at least until the

\footnotetext{
24 Roover, "The Concept of Just Price," p. 426.

25 Ibid., p. 429.
} 
Protestant Reformation. From the Catholic side, the period of the Counter-

Reformation was marked by some notable developments in economic theory as well as by important developments in the application of normative concepts of justice to prices and their regulation.

In this period, the work of the late scholastics - particularly those of the School of Salamanca - had a central and long-lasting influence in shaping Catholic views on prices, the operation of the market economy, and its relationship with state controls and regulation. ${ }^{26}$ The designation "School of Salamanca" refers to a distinct group of Iberian scholars of the sixteenth and early seventeenth centuries who followed in the footsteps of Francisco de Vitoria (c. 1483-1546). These authors - mostly Dominicans and, later, Jesuits employed and expanded the earlier Thomistic framework in order to deal with the new economic and political problems that arose in a time of rapid growth of business activity and European expansion into the "New World."

While for the most part their emphasis is on continuity with earlier Christian economic thinking, the Salamanca School combines a more elaborate understanding of the functioning of market economies and the role of prices with

\footnotetext{
${ }^{26}$ For an overview of the economic contributions of the late scholastics, see Alejandro A. Chafuen, Faith and Liberty: The Economic Thought of the Late Scholastics (Lanham: Lexington Books, 2003). Specifically about the School of Salamanca, see Marjorie Grice-Hutchison, The School of Salamanca: Readings in Spanish Monetary Theory 1544-1605 (Oxford: Clarendon Press, 1952) and André A. Alves and José M. Moreira, The Salamanca School (New York: Bloomsbury, 2013).
} 
greater practical skepticism about government intervention in general and price controls in particular. As emphasized by Alves and Moreira:

One of the key distinguishing features of the Salamanca School - and perhaps the most important characteristic of its economic thought - is its sophisticated understanding of the operation of the market economy. While the late Iberian scholastics did not, in most areas, offer a radical break with the past, they often put forth a more benevolent view of the functioning of the market economy than other earlier and contemporary thinkers. This view was also associated with a greater awareness of the dangers associated with undue political intervention in the market, which raised a broad scope of ethical concerns.

The late scholastics, to a greater extent than anyone before, incorporated into the idea of just price notions of supply and demand, as well as what can be regarded as an early understanding of the subjective theory of value (which was only explicitly and fully defined in economic theory in the second half of the nineteenth century).Thus, the founder of the Salamanca School, Francisco de Vitoria, describes the operation of market economies and the important role played by prices and their relationship with common estimation in the following manner:

27 André A. Alves and José M. Moreira, "Business Ethics in the School of Salamanca," in Handbook of the Philosophical Foundations of Business Ethics, ed. Christoph Luetge (Dordrecht: Springer, 2013), p. 216. 
It follows from this principle that wherever there is a marketable good for which there are many buyers, neither the nature of the good nor the price for which it was bought, that is today, how expensive it was, nor the toil and trouble it was to get it should be taken into account. When Peter sells wheat, the buyer need not consider the money Peter spent nor his work but, rather, the common estimation of how much wheat is worth. If, according to commons estimation, the bushel of wheat is worth four silver pieces and somebody buys it for three, this would constitute an injustice to the seller because the common estimation of a bushel of wheat is four silver pieces. In the same way, if that seller were to sell at a higher price, taking into account his expenses and his work, he would selling unjustly, because he should sell it according to the common estimation of the market.

Reinforcing his emphasis on the centrality of common estimation achieved through voluntary action in the context of the market, Vitoria then immediately goes on to clarify that other considerations used to deduce the just price and value of a good are only valid until the price has been established through common estimation, which should then be respected as the just price. In line with Vitoria, Domingo de Soto, another towering figure of the School of Salamanca, explains the notion of prices and their connection with utility, anticipating (although not in a fully consistent way) developments in economic 
theory that would only materialize again in an explicit form much later with the so-called marginalist revolution in the nineteenth century:

The price of things should not be calculated by their nature, but by the utility they serve to men. The reason for this conclusion is natural; because as the world and everything in it has been made for man, the things in common estimation ought to be worth as much as they serve men.

Or, in the words of another important representative of the school, Diego de Covarrubias y Leyva:

The value of an article does not depend on its essential nature but on the estimation of men, even if that estimation be foolish. Thus, in the Indies wheat is dearer than in Spain because men esteem it more highly, though the nature of the wheat is the same in both places.

In line with the earlier Christian doctrine on the just price, it was deemed to include both the natural price (associated with common estimation in the market in the absence of coercion, fraud, monopoly, or monopsony) and the legal price (fixed by a legitimate authority, but not arbitrarily, since the price was restricted by the need to be in line with the pursuit of the common good).

Also in line with the earlier doctrine, exceptions were allowed for price controls. But distrust was on the rise about the potential ill effects of these

${ }^{29}$ Domingo de Soto, De iustitia et iure - facsimile of the 1556 Latin edition accompanied with a Spanish translation (Madrid: Instituto de Estúdios Políticos, 1968 [1556]), book vi, q. ii, a. iii.

30 Quoted in Marjorie Grice-Hutchison, Early Economic Thought in Spain 1177-1740 (London: George Allen \& Unwin), p. 100. 
interventions and detrimental unintended consequences of regulation that jeopardized the common good. This inspired leading Catholic thinkers of the period to issue strong warnings about these risks. While legal prices that shied away from common estimation were admitted as valid in principle, skepticism about them grew deeper and geared Catholic economic thought in a direction that was more receptive to the operation of market economies (in the absence of coercion, fraud, monopoly, or monopsony) ${ }^{31}$ than in earlier periods.

Elegido offers a useful synthesis of the prevalent views of the School of Salamanca on prices and market economies:

In my view the leading authors of the Salamanca School can contribute three key ideas to a modern discussion of justice in pricing. They used a substantive standard for assessing the justice of exchanges; they claimed that the fundamental standard of commutative justice is equivalence in value; and, finally, they argued that the best indicator of the value of a good is the price that it fetches in an open market.

The inclination of the late scholastics (and particularly within the School of Salamanca) to be skeptical about government intervention in the market and particularly about the imposition of price controls even led Raymond de Roover,

31 These conditions may be seen as the central (although not exclusive) tenets of a business culture compatible with Catholic Social Teaching. See André Azevedo Alves, Philip Booth, and Barbara Fryzel, "Business Culture and Corporate Social Responsibility: An Analysis in the Light of Catholic Social Teaching with an Application to Whistle-Blowing," The Heythrop Journal (April 2016).

32 Juan Manuel Elegido, "The Just Price: Three Insights from the Salamanca School," Journal of Business Ethics, vol. 90, no.1 (2009), p. 30. 
in his highly influential article on the concept of the just price, to consider it a weakness on their part:

One weakness of the scholastic doctors was that they were interested only in laying down principles and tended to overlook practical difficulties, which, they claimed, did not concern the theologians but were the province of the "politicians." An extreme position was taken by Martin Azpilcueta (1493-1587), better known as Navarrus, who opposed all price regulation because it was unnecessary in times of plenty and ineffective or harmful in times of dearth. Several others, among them Molina, looked upon price regulation with the same disfavor.

A definitive judgment on whether this strong inclination on the part of Azpilcueta, Molina, and others ought to be considered a weakness or a strength of their analysis will, of course, be largely dependent upon one's own contemporary view about the desirability and usefulness of price controls. But regardless of that judgment, it is fair to say that, in this period, Catholic views on the subject evolved toward a more favorable view of the operation of competitive and open market economies and toward a more skeptical position on the adoption of price controls, even if the Catholic thinkers continued to admit price controls as being legitimate in principle. ${ }^{34}$ Although not unchallenged, this continues to be the prevailing view emerging from the Catholic tradition and an

33 Roover, "The Concept of the Just Price," p. 426.

34 For a more detailed analysis of the late scholastics' views on price controls, see also Chafuen, Faith and Liberty, pp. 85-90. 
accurate description of other Christian perspectives on price controls and market economies.

\subsection{Protestant Thought on Price Controls after the Reformation}

\subsubsection{The Protestant Reformation and Economic Thought}

When the Protestant Reformation began in sixteenth-century Europe, the capitalist economic model was not excluded from its criticisms. As Thelma McCormack very well explains by referring to the arguments of R. H. Tawney and Émile Durkheim, capitalism in its initial form was seen by many as providing "economic growth at the expense of social purpose" 35 and as suffering from "a chronic debilitation of morale in terms of an ethical vacuum, an organic division of labour without a larger awareness of interdependency, economic activity without a guild ethic."

In this context, and given the apparent inertia of the established Catholic Church to address these changes and its consequences, the Reformation started

\footnotetext{
35 Thelma McCormack, "The Protestant Ethic and the Spirit of Socialism," The British Journal of Sociology, vol. 20, no. 3 (September 1969), p. 266.

${ }^{36}$ Ibid., p. 267. These considerations may be justified by the enormous changes capitalism brought, combined with not only the discovery of new routes of trade - which included not only the transformation of small villages into big cosmopolitan, urban towns and the growth of population with the increasing movement of people and goods - but also with important changes in the labor market that resulted in labor shortages and unemployment (Cf. ibid., pp. 269270).
} 
as a protest within the Church, with the main objective of trying to "bring order out of chaos by providing a new normative framework." 37 This modern norm the Protestant ethic - favored the differentiation of roles in society and the interaction among them, this being fundamental to the definition of new roles for social participation and the division of labor. Furthermore, the Protestant ethic also carried a tradition of Natural Law. This combination began with Hugo Grotius in 1625, continued with Pufendorf, Hutcheson, and Adam Smith, and provided "the theoretical foundations of political economy," including "the nucleus of value and price theory." 38 (Note: For an exposition of Smith's, Pufendorf's, and Hutcheson's views in relation to antitrust, see Chapter 4 by Elzinga and Crane.)

\subsubsection{Value and Price Theory in Pufendorf, Hutcheson, and Smith}

The main common element concerning the definition of value among the authors of this tradition is the determination of just price by using a combination of a good's utility and the costs of labor expended in its production. In 1672, Samuel Pufendorf developed his influential theory of value and price in his De Jure Naturae et Gentium, where he defines price as being "a moral quality of things and actions in so far as they are understood to serve some purpose in common life." 39 Three elements can thus be distinguished in the process of defining a

37 Ibid., p. 270.

38 Jefrey T. Young, "Law and Economics in the Protestant Natural Law Tradition: Samuel Pufendorf, Francis Hutcheson, and Adam Smith," Journal of the History of Economic Thought, vol. 30, no.3 (September 2008), p. 283.

${ }^{39}$ Quoted in ibid., p. 284. 
certain thing's price. The first element is subjective valuation. This reflects the usefulness of a certain thing for human life or the thing's ability to contribute to a more pleasant life. ${ }^{40}$ Scarcity is the second element. It is perhaps the most important one when considering high prices, since there is a tendency for price to be lower when quantity is greater, even with things "which men are least able to do without." ${ }^{11}$ The last element is the process of production, which reflects the complexity of the cost factors involved in the making of the thing. These factors include, among others, the difficulty of the production, the quantity of workers needed, and the positions they occupy.

As for the contexts in which prices can be formed, Pufendorf explains that, in the state of nature, where transactions occur only occasionally, prices are agreed between the parts involved in the transaction. In organized states,

${ }^{40}$ In this point, however, Pufendorf recognizes that there are some things that, despite having no price, are extremely useful for human life, namely, things that "are and should be exempt from dominion" (e.g., the air and the open ocean), things that "are removed from commerce by law and/or custom" (e.g., sacred sites or articles), and things that "cannot be held separately, although they are accessory to things the price of which they influence" (e.g., a beautiful landscape) (quoted in ibid., p. 294). Following Pufendorf's rationale, Hutcheson also enumerates some objects for which prices cannot be determined, such as those things "naturally destined for community, or cannot come into commerce but as appendages of something else" (Francis Hutcheson, Philosophiae moralis institution compendiaria, with $A$ Short Introduction to Moral Philosophy (Indianapolis, IN: Liberty Fund, 2007), p. 280, http://oll.libertyfund.org/title/2059).

${ }^{41}$ Quoted in Young, "Law and Economics in the Protestant Natural Law Tradition," p. 285. Adam Smith also associates the idea of scarcity with that of price and property when he recognizes that the air, the running water, and the sea cannot be owned because "they cannot be lessened or impaired by use, nor can anyone be injured by the use of them." Adam Smith, Lectures on Justice, Police, Revenue and Arms (Oxford: Clarendon Press, 1986), i.60. 
however, prices can be set either by authorities or "by the general valuation and judgement of men, with the further consent of those who are the parties to bargain." ${ }^{2}$ When the determination of the price follows a consented judgment of men, the established price is known as "common or natural price," which is taken as the just price. In this case, the merchant is allowed to reflect in the price the costs of labor and expenses borne to obtain the product, being thus able to sell more dearly and to profit from the sale of a product without violating the just price:

But merchants can include in their estimation the time they have spent, the plans they have formed, and the troubles they have met in acquiring, preserving, or distributing their merchandise, as well as all necessary expenses for the labour of their servants ... it would surely be inhuman, and likely to destroy the industry of men, to try to allow a man for his business, or any other sort of occupation, no more profit than barely permits him to meet his necessities by frugality and hardships.

Some decades after Pufendorf developed his theory, Francis Hutcheson developed his own account of value and price in two of his works, System of Moral Philosophy (1747) and A Short Introduction to Moral Philosophy (1755), in which he recognized the contribution by Pufendorf. According to Hutcheson, prices are determined by an equal influence of the elements of demand and supply. The author places a special emphasis put on the latter, which he refers to

42 Quoted in Young, "Law and Economics in the Protestant Natural Law Tradition," p. 285.

${ }^{43}$ Quoted in ibid., p. 285. 
as "difficulty." The supply that determines the price thus reflects effort expended and includes not only the quantity of the good, but also subjective factors such as the toil required for production, the genius or ingenuity of the producer, and even the life standards of the merchant:

From what we said about the grounds of price, 'tis plain that in estimating the values of goods \{in any place\}, we are not only to compute the disbursement made in buying, importing, and keeping them safe, with the interest of money thus employed; but also the pains and care of the merchant; the value of which is to be estimated according to the reputable condition in which such men live, and to be added to the other charges upon the goods. This price of the merchant's labour < and care $>$ is the foundation of the ordinary profit of merchants.

For Adam Smith, an account of the theory of value and price can be found in his conception of justice. Under the designation of "natural price," Smith sees the just price as a combination of the utility of the good with all the aspects involved in its creation. In the beaver and deer story that the author tells in his Wealth of Nations, he introduces the notion of the right to the fruits of one's labor with the claim that the hunter shall receive something in return for his labor. ${ }^{45}$ This right is also seen as a form of equity - another important concept presented by Smith

${ }^{44}$ Hutcheson, Philosophiae moralis, p. 284.

45 In Adam Smith's own words: "the property which every man has in his own labour, as it is the original foundation of all other property, so it is the most sacred and inviolable" (Adam Smith, An Inquiry into the Nature and Causes of the Wealth of Nations (Indianapolis, IN: Liberty Fund, 1976): I.x.c.12). 
in his Lectures on Jurisprudence - which is related to retributive justice, even being used synonymously with the concept of natural justice:

Servants, labourers, and workmen of different kinds, make up the far greater part of every great political society. But what improves the circumstances of the greater part can never be regarded as an inconveniency to the whole. No society can surely be flourishing and happy, of which the far greater part of the members are poor and miserable. It is but equity, besides, that they who feed, cloath and lodge the whole body of the people, should have such a share of the produce of their own labour as to be themselves tolerably well fed, cloathed and lodged.

Under the influence of and inspired by the notion of price as defined by Samuel Pufendorf and Francis Hutcheson, ${ }^{47}$ Smith goes beyond those two authors and elaborates on situations where price controls should be implemented.

The most known example of this kind of mechanism can be found on the market for loans, where Smith clearly favors the imposition of a price ceiling on interest rates. This usury law - as it is commonly called - aimed mainly to reduce the flow of high-risk loans and increase the availability of money to be borrowed by "sober" and "prudent" men. According to Smith, the absence of a legal rate ceiling would result in higher interest rates and would consequently concentrate

46 Ibid., I.viii.36.

47 This influence is extensively explored by Andrew Skinner, "Pufendorf, Hutcheson and Adam Smith: Some Principles of Political Economy," Scottish Journal of Political Economy, vol. 42, no. 2 (May 1995), pp. 165-182, or by Enzo Pesciarelli, "Aspects of the Influence of Francis Hutcheson on Adam Smith," History of Political Economy, vol. 31, no. 3 (1999), pp. 525-545. 
loans in the hands of "prodigals and projectors," who would be likely to use it for speculative and unproductive investments. Following this rationale, Smith proposes the legal rate "to be somewhat above," but not "much above the lowest market rate," so as to have "a great part of the capital of the country ... thrown into the hands in which it is most likely to be employed with advantage." ${ }^{48}$ By defining the interest rate ceiling slightly above the market price, Smith's main intention was to reduce incentives for high-risk loans, since, with low interest rates, high-risk lenders would not receive the full risk premium of the loans required to make them feasible.

Smith was also in favor of regulations in the banking sector. His main commentators justify this by reference to two events in Scotland that shaped Smith's economic thinking: The "small note mania" and the Ayr Bank Crisis. Having recognized the dangers posed by those situations and wishing to prevent them from occurring in the future, Adam Smith suggested two main regulating

48 Smith, Wealth of Nations, II.iv.15.

${ }^{49}$ Adam Smith's perspective on the market for loans and on usury laws is thoroughly analyzed by Joseph M. Jadlow, "Adam Smith on Usury Laws," The Journal of Finance, vol. 32, no. 4 (September 1977), pp. 1195-1200.

50 As explained by Hugh Rockoff, "Adam Smith on Money, Banking, and the Price Level," in The Oxford Handbook of Adam Smith, eds. Christopher J. Berry, Maria Pia Paganelli, and Craig Smith (Oxford: Oxford University Press, 2013), pp. 307-332, these two shocks had a significant impact on the Scottish banking system, as well as repercussions on international financial institutions, having resulted in a "V-shape" economic recession. The "small notes mania" was characterized by the issuing of "redeemable notes for very small sums of money," while the Ayr Bank Crisis refers to a financial crisis in 1772 - "the first modern banking panic faced by the Bank of England" - on which Ayr Bank was "at the very epicentre of the boom, and was the trigger of the subsequent crash" that was the result of bad investment decisions made by the bank (ibid., pp. 310315). 
tools. The first corresponded to the real bills doctrine, according to which banks should only issue money in exchange for short-term real bills. The second consisted of a prohibition of small notes - for Smith considered this practice to have a speculative character and that it penalized poor people. 5

Smith himself recognized that these kinds of controls were exceptions to his main theory of natural liberty and laissez faire, but he considered them necessary for assuring a greater good:

Such regulations may, no doubt, be considered as in some respects a violation of natural liberty. But those exertions of the natural liberty of a few individuals, which might endanger the security of the whole society, are, and ought to be, restrained by the laws of all governments, of the most free as well as of the most despotical. The obligation of building party walls, in order to prevent the communication of fire, is a violation of natural liberty exactly of the same kind with the regulations with the regulations of the banking trade which are here proposed. 5

51 "Where the issuing of bank notes for such very small sums is allowed and commonly practised, many mean people are both enabled and encouraged to become bankers.... But the frequent bankruptcies to which such beggarly bankers must be liable, may occasion a very considerable inconveniency, and sometimes even a very great calamity to many poor people who had received their notes in payment" (Smith, Wealth of Nations, II.ii.90).

52 Ibid., II.i.94. 


\subsection{Luther and Price Theory}

Martin Luther is a prominent figure in Protestant thought. His importance and influence in European history during the sixteenth and seventeenth centuries is undeniable, with his intellectual impact lasting well into the present day through Protestantism. His economic theory is founded on the Christian virtue of charity, with a particular emphasis given to the seventh commandment - you shall not steal - "which extends that subject from regular theft to the idea of relieving a person of his property against his will by furtive practices in the marketplace." Despite recognizing its necessary character, Luther had an ambiguous attitude regarding trade. He considered that buying and selling would always turn people into victims of greed, "for businessmen will cheat and lie." 54 Given this inevitability, Luther believed that the only solution for the greedy disposition of merchants was to have prices determined by the estimation of wise and honest men appointed by temporal authorities. According to this theory, developed in On Trade and Usury, the just price would be based on the real cost of the product, combined with the necessary profit for the merchant to continue his economic activity and sustain his family. In the absence of fixed prices, the just price would be the one decided in the common market:

It is fair and right that a merchant make as much profit on his wares as will cover his cost and pay him for his trouble, his labor, and his risk ... one can truly give you no instructions but

53 Odd Langholm, "Martin Luther's Doctrine on Trade and Price in Its Literary Context," History of Political Economy, vol. 41, no. 1 (2009), p. 92. 54 Ibid., p. 94. 
leave it to your conscience to be careful not to overcharge your neighbor by your greed but seek your modest living.

Influenced by pre-Reformation Catholic ideas, Luther also condemned the practices of fraud, understood as "fooling the opposite party," 56 and economic coercion, seen as "exploiting the need of the opposite party in order to obtain more favorable terms of exchange." 57 As for collusion and monopoly, the critique is absolute. Luther considers that those who engage in trade just to control the supply or price of certain goods and to make money in that manner are "unChristian," practice "selfish business," and "should not be tolerated."

In general, the Protestant tradition's theory of value and price defends the just price as an arrangement that combines cost estimates with a fair profit for merchants. Furthermore, the claims for compensation associated with cost elements are grounded in the account of natural property rights and markets. And the exchange of goods is understood as "embedded in social institutions" and as "a form of human interaction and cooperation," which is essential for men to live in a peaceful society.

Within this Protestant natural-law tradition, it becomes possible to distinguish the perspective of the political economists (including Samuel

${ }^{55}$ Quoted in ibid., p. 96.

${ }^{56}$ According to Luther, the most common forms of fraud included: "using false weights, measures or coins; overestimating merchandise; overcharging customers; selling false or bad merchandise; taking advantage of customers by nimbleness, queer finances, or dexterous tricks" (quoted in ibid., p. 98).

${ }^{57}$ Ibid., p. 92.

${ }^{58}$ Quoted in ibid., p. 103.

${ }^{59}$ Young, "Law and Economics in the Protestant Natural Law Tradition," p. 288. 
Pufendorf, Francis Hutcheson, and Adam Smith) from Martin Luther's point of view. While the former have a more positive view of the market economy, the latter aligns with a more restrictive and distrustful vision of commercial exchanges.

\subsection{Conclusion}

As one would expect, contemporary Christians' views on mechanisms of price control are largely shaped by the positions developed centuries ago, with a special emphasis on the Thomist framework and its contribution of the definition of the justum pretium.

In the more heterogeneous context of Protestant denominations, there is naturally a greater variety of positions regarding this theme. Some have a more positive perspective of the market economy, while others argue in favor of greater restrictions and take a more skeptical opinion about commercial transactions. A detailed analysis of this heterogeneity would go vastly beyond the scope and possibilities of this chapter, but we should nevertheless acknowledge it.

Although there are various Catholic views on price controls, Catholic positions on the subject have a more easily discernible central core. This is not only because there is greater unity and centralization in the Catholic Church but also because of the orientations provided by the Catechism. The general framework of the idea of price controls and market economies is built upon earlier advances in Catholic thought. It can be found in John Paul II's encyclical letter Centesimus Annus, 32: "A person who produces something other than for 
his own use generally does so in order that others may use it after they have paid a just price, mutually agreed upon through free bargaining." Additionally, one of the most significant references appears in the discussion of the seventh commandment:

The seventh commandment forbids theft, that is, usurping another's property against the reasonable will of the owner.

Even if it does not contradict the provisions of civil law, any form of unjustly taking and keeping the property of others is against the seventh commandment: thus, deliberate retention of goods lent or of objects lost; business fraud; paying unjust wages; forcing up prices by taking advantage of the ignorance or hardship of another. The following are also morally illicit: speculation in which one contrives to manipulate the price of goods artificially in order to gain an advantage to the detriment of others; $[. .$.$] .$

In Centesimus Annus, it is also possible to identify certain specific circumstances where the regulation of prices appears to be suggested, even though it does not necessarily imply price controls imposed by the state:

The State, however, has the task of determining the juridical framework within which economic affairs are to be conducted, and thus of safeguarding the prerequisites of a free economy, which presumes a certain equality between the parties, such that one

60 Catechism of the Catholic Church, p. 2408.

61 Ibid., p. 2409. 
party would not be so powerful as practically to reduce the other to subservience.

These specific circumstances, however, cannot be defined a priori and are not independent of judgment on economic theory, as they will be fundamental to evaluate implications of both prices and regulation on the common good. In order to analyze these particular cases that may justify some sort of intervention, more detailed and in-depth studies and analyses are necessary.

Perhaps the best way to synthesize the Christian position on price controls (to the extent a common Christian position can be ascertained) is in terms of a general inclination to respect the just price. The just price is mostly understood in contemporary terms as the free market price voluntarily agreed upon by the parties in the absence of fraud, coercion, or situations of extreme need. This implicitly recommends against any form of controls on prices that respect those basic conditions. At the same time, there is a recognition that in certain relatively exceptional situations, the prices set by private actors may be in violation of the seventh commandment and, for that reason, may justify (or even require) the regulation of prices.

62 Centesimus Annus, p. 15.

63 A good example is Debra Wilson, "Price Gouging, Construction Cartels or Repair Monopolies? Competition Law Issues Following Natural Disasters," Canterbury Law Review, vol. 20 (2014), pp. 53-90. 